Stannum : Jurnal Sains dan Terapan Kimia

Website: https://journal.ubb.ac.id/index.php/stannum

doi:

Research paper

\title{
Total Phenolic and Antioxidant Capacity of Acetone Extract of Tristaniopsis meguensis Leaves
}

\section{Total Fenolik dan Kapasitas Antioksidan dari Ekstrak Aseton Daun Tristaniopsis merguensis}

\author{
0. Roanisca ${ }^{1}$, R. G. Mahardika ${ }^{1}$, dan F. I. P. Sari ${ }^{1}$ \\ 1) Department of Chemistry, Universitas of Bangka Belitung \\ Kampus Terpadu Universitas Bangka Belitung, Bangka, Bangka Belitung, 33172 \\ *Corresponding author: robbygusmahardika@gmail.com
}

\begin{abstract}
The purpose of this study was to determine the total phenolic and antioxidant capacity of Tristaniopsis merguensis leaf acetone extract. In this study extraction using the maceration method for 3 days with a ratio of dry leaves and solvents of 1: $10(\mathrm{w} / \mathrm{v})$. Analysis of total polyphenols in this study was carried out using the Follin-Ciocalteu method. Total polyphenols were measured based on gallic acid standards. The antioxidant capacity is calculated based on the DPPH method. The results of this study, obtained extract yield of 9.34\%. The total phenolic content of the Tristaniopsis merguensis leaf acetone extract was $215.22 \mathrm{mg}$ GAE / g DW. While the antioxidant capacity of the acetone extract has an IC50 value of $22,1454 \mu \mathrm{g} / \mathrm{mL}$.
\end{abstract}

Kata kunci: fenolik, aktivitas antioksidan, ekstraksi

\section{PENDAHULUAN}

Tristaniopsis merguensis (Griff.) merupakan salah satu pohon yang banyak tersebar di hutan Kepulauan Bangka Belitung. Spesies ini merupakan anggota dari genus Tristaniopsis dengan famili Myrtaceae. Pohon Tristaniopsis merguensis (Griff.) dikenal oleh masyarakat bangka sebagai pohon pelawan. Pohin ini dimanfaatkan oleh masyarakat untuk mendapatkan madu pelawan dan jamur pelawan, yang dipercaya memiliki banyak khasiat. Madu pelawan memiliki rasa pahit bercampur rasa manis yang dipercaya sebagai obat batuk dan obat antidiabetes. Manfaat pohon pelawan sebagai obat tradisional sangat banyak, tetapi informasi metabolit sekunder dari Tristaniopsis merguensis masih terbatas khususnya di Indonesia.

Berdasarkan penelitian terdahulu, kajian fitokimia dari daun pada genus Tristaniopsis mengandung 0,03\% flavonoid, 0,95\% saponin, dan 1,04\% tanin. Senyawa aktif mayor dari genus Tristaniopsis yaitu senyawa golongan fenolik seperti flavonoid dan tanin. Senyawa fenolik yang terkandung dalam genus Tristaniopsis mempunyai keunikan fenol 
terglikosilasi. Tingginya kandungan fenolik pada genus Tristaniopsis dan khasiat pada pohon pelawan (Tristaniopsis merguensis) yang banyak, membuat peneliti tertarik untuk mengungkap kandungan fenolik total ekstrak daun pelawan (Tristaniopsis merguensis) Bangka (Enggiwanto, Istiqomah, Daniati, Roanisca, \& Mahardika, 2018).

Pada umumnya, ekstrak tumbuhan yang mengandung senyawa fenolik dengan aktivitas antioksidan yang tinggi dapat dijadikan prekursor obat herbal (Mokgope 2006). Oleh sebab itu penelitian ini akan mengkaji total fenolik dan kapasitas antioksidan dari ekstrak daun Tristaniopsis merguensis.

Perkembangan penggunaan antioksidan saat ini semakin pesat. Kapasitas antioksidan suatu senyawa atau ekstrak sering dikaitkan dengan penggunaannya sebagai obat beberapa penyakit degeneratif seperti jantung dan kanker. Selain digunakan sebagai obat antioksidan juga mulai dimanfaatkan sebagai bahan aditif makan untuk meningkatkan nilai gizinya (Hanani, Mun, \& Sekarini, 2005). Oleh sebab itu kebutuhan akan pencarian ekstrak atau senyawa baru yang kuat akan antioksidan masih menjadi penelitian yang menarik untuk diteliti mengingat kebutuhan akan antioksidan semakin meningkat.

Penelitian ini bertujuan untuk menentukan total denolik dan kapasitas antioksidan ekstrak aseton Tristaniopsis merguensis.

\section{METODOLOGI}

\section{Bahan}

Bahan yang digunakan pada penelitian ini meliputi metanol p.a, aseton, DPPH, asam galat, dan kertas saring.

\section{Alat}

Peralatan yang digunakan yaitu rlenmayer, gelas ukur, corong Büchner, rotary evaporator, neraca analitik, pipet tetes, tabung reaksi, batang pengaduk, spatula, labu ukur, rak tabung reaksi, spekrofotometer UV-Vis 1800 Shimadzu dan hot

plate.

\section{Prosedur \\ Preparasi Sampel}

Daun pelawan (Tristaniopsis merguensis Griff) yang digunakan dalam penelitian ini berasal dari Desa Sempan, Kecamatan Pemali, Kabupaten Bangka. Selanjutnya sampel tersebut akan dikeringkan di udara terbuka, setelah itu digiling menjadi serbuk kering yang selanjutnya siap untuk dimaserasi.

\section{Ekstraksi Metabolit Sekunder}

Serbuk kering daun pelawan sebanyak $1 \mathrm{~kg}$ dimaserasi dengan pelarut aseton sebanyak 10 L selama $3 \times 24$ jam. Maserasi dilakukan tiga kali setiap $1 \times 24$ jam dilakukan pergantian pelarut dan penyaringan dengan menggunakan corong buchner untuk memisahkan filtrat dengan residu. Filtrat yang diperoleh dipekatkan dengan rotary evaporator vacuum hingga diperoleh ekstrak pekat aseton (Dungir dkk., 2012).

\section{Total Fenolik}

Total fenolik dilakukan secara kuantitatif dengan metode Follin-Ciocalteu [22]. Ekstrak dilarutkan dengan metanol dengan konsentrasi $10 \mathrm{mg} / \mathrm{mL}$. Ekstrak ini kemudian diambil 0,5 ml dan dimasukkan ke dalam tabung reaksi yang mengandung $2,5 \mathrm{~mL}$ reagen FollinCiocalteu $10 \%$ dan $2,5 \mathrm{~mL} \quad \mathrm{Na}_{2} \mathrm{CO}_{3} \quad 7,5 \%$. Kemudian sampel diinkubasi pada suhu $27^{\circ} \mathrm{C}$ selama 30 menit. Sebagai blanko, 0,5 mL metanol ditambahkan dengan $2,5 \mathrm{~mL}$ reagen Follin-Ciocalteu $1 \%$ dan 2,5 mL $\mathrm{Na}_{2} \mathrm{CO}_{3} 7,5 \%$. Perubahan absorbansi diukur pada panjang gelombang $765 \mathrm{~nm}$ dengan spektroskopi UVVis. Kontrol positif menggunakan asam galat dengan variasi konsentrasi asam galat. Total ekstrak fenolik dihitung berdasarkan kurva asam galat standar kalibrasi dan dinyatakan dalam mg ekuivalen asam galat (EAG) / g ekstrak kering.

\section{Uji Antioksidan}

Aktivitas antioksidan menggunakan metode DPPH secara spektroskopi. Ekstrak daun pelawan dibuat dalam konsentrasi berbedabeda. Masing-masing konsentrasi dimasukkan dalam tabung reaksi sebanyak $1 \mathrm{~mL}$ dan larutan DPPH $100 \mu \mathrm{g} / \mathrm{mL} 1 \mathrm{~mL}$ serta metanol p.a. $2 \mathrm{~mL}$. Larutan yang telah ditambah DPPH diinkubasi selama 30 menit pada suhu $37^{\circ} \mathrm{C}$. Larutan tersebut diukur absorbansinya menggunakan spektroskopi UV-Vis pada $\lambda$-maksimum. IC $_{50}$ yang didapat dari nilai $\mathrm{x}$ dengan $\mathrm{y}=50$ dari hasil persamaan regresi linier antara persentase inhibisi dengan konsentrasi. Inhibisi dihitung berdasarkan persamaan berikut:

Inhibisi \%= $\left[\left(A_{\text {kontrol }}-A_{\text {sampel }}\right) / A_{\text {kontrol }}\right] \times 100$ 


\section{HASIL DAN PEMBAHASAN}

Analisis total fenolik pada penelitian ini dilakukan dengan menggunakan metode FollinCiocalteu yang diukur berdasarkan standar asam galat (GAE). Standar asam galat yang digunakan yaitu 10, 30, 40, 50, dan 80 ppm dan diukur ada panjang gelombang $765 \mathrm{~nm}$. Absorbansi yang didapat diplot terhadap konsentrasi menghasilkan persamaan garis lurus pada gambar 1 . Persamaan garis dari plot ini yaitu $y=0,018 x+0,2446$ dengan $R^{2}=0,9924$.

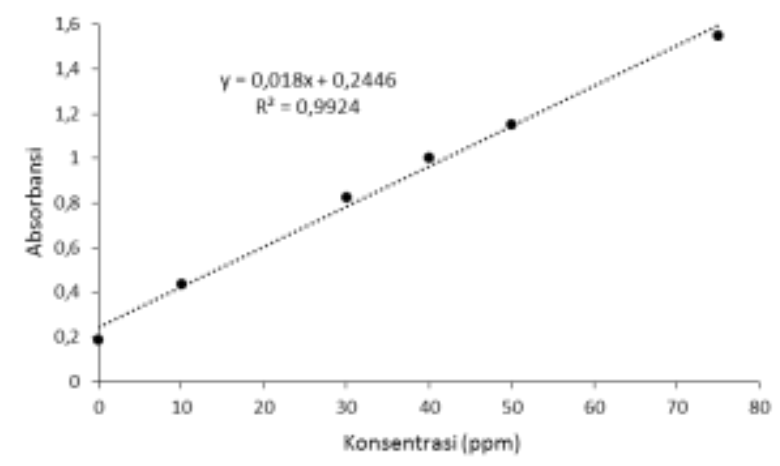

Pengukuran ekstrak aseton daun Tristaniopsis meguensis didapatkan absorbansi
0,632. Jika diplotkan dalam persamaan garis lurus tersebut didapatkan konsentrasi sebesar 21,522 ppm. Sehingga konsentrasi total fenolik dari ekstrak daun Tristaniopsis merguensis sebesar 215,22 mg GAE/g ekstrak. Nilai ini jauh lebih besar dibandingkan kandungan fenolik pada ekstrak bunga rosela (Hibiscus sabdariffa L.) 21,2 g GAE/g ekstrak, maupun pada ekstrak Citruss reticulate L.) 28, mg GAE/g ekstrak (Safdar et al., 2017) (Riza \& Susanti, 2013).

\section{Aktivitas Antioksidan}

Aktivitas antioksidan pada penlitian ini menggunakan metode DPPH dengan konsentrasi ekstrak 10, 20, 30, dan $40 \mu \mathrm{g} / \mathrm{mL}$. Ekstrak diukur pada panjang gelombang maksimum $516 \mathrm{~nm}$ (gambar 2).

Pada panjang gelombang tersebut dilakukan pengkuran absrobansi terhadap ekstrak Tristaniopsis merguensis. Data pengkuran aktivitas antioksidan disajikan pada tabel 1 .

Tabel 1. pengkuran aktivitas antioksidan

\begin{tabular}{|c|c|c|c|c|c|c|}
\hline \multirow{2}{*}{$\begin{array}{c}\text { Konsentrasi } \\
\text { Ekstrak } \\
(\mu \mathrm{g} / \mathrm{mL})\end{array}$} & \multicolumn{2}{|c|}{ Absorbansi } & \multirow{2}{*}{$\begin{array}{c}\% \\
\text { Inhibisi }\end{array}$} & \multirow{2}{*}{$\begin{array}{c}\text { Persamaan } \\
\text { Linier }\end{array}$} & \multirow{2}{*}{$\begin{array}{c}\mathrm{IC}_{50} \\
(\mu \mathrm{g} / \mathrm{mL})\end{array}$} & \multirow{2}{*}{ Ket. } \\
\hline & Blanko & Sampel Uji & & & & \\
\hline 10 & \multirow{4}{*}{0.921} & 0,673 & 26,927 & \multirow{4}{*}{$\begin{array}{c}y=1,8588 x \\
+9,5005 R^{2} \\
=0,9963\end{array}$} & \multirow{4}{*}{22,1454} & \multirow{4}{*}{ Kuat } \\
\hline 20 & & 0,482 & 47,666 & & & \\
\hline 30 & & 0,306 & 66,775 & & & \\
\hline 40 & & 0,161 & 82,519 & & & \\
\hline
\end{tabular}

Menurut Suratmo (2009) dalam Putri dkk. (2015) kapasitas antioksidan dengan metode $\mathrm{DPPH}$ dikelompokkan berdasarkan nilai $\mathrm{IC}_{50}$. Aktivitas antioksidan dikategorikan sangat kuat jika nilai $\mathrm{IC}_{50}<50 \mu \mathrm{g} / \mathrm{mL}$, kuat mempunyai nilai $\mathrm{IC}_{50} 50-100 \mu \mathrm{g} / \mathrm{mL}$, sedang nilai IC I0 $_{50}$ 100-250 $\mu \mathrm{g} / \mathrm{mL}$, dan lemah 250-500 $\mu \mathrm{g} / \mathrm{mL}$. Nilai $\mathrm{IC}_{50}$ ekstrak aseton Tristaniopsis merguensis adalah $22,1454 \mu \mathrm{g} / \mathrm{mL}$, maka ekstrak tersebut memiliki aktivitas antioksidan yang sangat kuat (Enggiwanto et al., 2018)

Aktivitas antioksidan ekstrak aseton Tristaniopsis merguensis ini lebih lemah jika dibandingan dengan ekstrak etanolnya dengan nilai $\mathrm{IC}_{50} \quad 18,2772 \mu \mathrm{g} / \mathrm{mL}$. Tetapi jika dibandingkan dengan ekstrak tanaman lain, aktivitas antioksidan ekstrak aseton daun Tristaniopsis merguensis jauh jauh lebih kuat dibandingkan ekstrak tanaman lain seperti ekstrak batang pakis (Alsophila glauca J. Sm) dan ekstrak etil asetat Cratoxylum glaucum dengan nilai $\mathrm{IC}_{50} \quad 178,4 \mu \mathrm{g} / \mathrm{mL}$ dan 32,212 $\mu \mathrm{g} / \mathrm{mL}$ (Wahdaningsih, Setyowati, \& Wahyuono, 2011) (Mahardika \& Roanisca, 2018).

Sangat kuatnya aktivitas antioksidan ini tidak terlepas dari tingginya kandungan total fenolik dari ekstrak aseton Tristaniopsis merguensis. Senyawa golongan fenolik ini yang berpengaruh pada tingginya aktivitas antioksidan ekstrak aseton Tristaniopsis merguensis.

\section{KESIMPULAN}

Berdasarkan penelitian yang telah dilakukan didapatkan rendemen ekstrak 9,34\%. Kandungan total fenolik ekstrak aseton daun Tristaniopsis merguensis sebesar 215,22 mg GAE/g ekstrak kering. Sedangkan kapasitas 
antioksidan ekstrak aseton memiliki nilai $\mathrm{IC}_{50}$ $22,1454 \mu \mathrm{g} / \mathrm{mL}$. Sangat kuatnya aktivitas antioksidan ini tidak terlepas dari tingginya kandungan total fenolik dari ekstrak aseton Tristaniopsis merguensis.

\section{UCAPAN TERIMA KASIH}

Peneliti mengucapkan terima kasih kepada Kementrian Riset, Teknologi, dan Pendidikan Tinggi melalui hibah Penelitian Dosen Pemula (PDP) sesuai dengan Surat Keputusan Nomor 7/E/KPT/2019 dan Perjanjian / Kontrak Nomor 052/SP2H/LT/DRPM/2019 dan 187.0/UN.50.3.1/PP/2019.

\section{REFERENSI}

Enggiwanto, S., Istiqomah, F., Daniati, K., Roanisca, O., \& Mahardika, R. G. (2018). Ekstraksi Daun Pelawan (Tristaniopsis merguensis) Sebagai Antioksidan Menggunakan Microwave Assisted Extraction ( MAE ). Indonesian Journal of Pure and Applied Chemistry, 1(2), 50-55.

Hanani, E., Mun, A., \& Sekarini, R. (2005). Identifikasi Senyawa Antioksidan Dari Kepulauan Seribu. Majalah IImu Kefarmasian, II(3), 127-133.

Mahardika, R. G., \& Roanisca, O. (2018). Antioxidant Activity And Phytochemical of Extract Ethyl Acetat Pucuk Idat (Cratoxylum glaucum). Indo. J. Chem. Res, 5(2), 481-486.

Mokgope, L. B. 2006. Cowpea Seed Coats and Their Extracts : Phenolic Composition and Use as Antioxidants in Sunflower Oil. South Africa: University of Pretoria

Putri, A.A.S., Hidajati, N. (2015). Uji aktivitas antioksidan senyawa fenolik ekstrak metanol kulit batang tumbuhan nyiri batu (Xylocarpus moluccensisi). UNESA Journal of Chemistry, 4. 1-6.

Riza, A., \& Susanti, H. (2013). penetapan kadar fenolik total ekstrak metanol kelopak bunga rosella merah (Hibiscus sabdariffa Linn) dengan variasi tempat tumbuh secara spektrofotometri. Jurnal Ilmiah Kefarmasian, 33(3), 324-333.

Safdar, M. N., Kausar, T., Jabbar, S., Mumtaz, A., Ahad, K., \& Saddozai, A. A. (2017). Extraction and quantification of polyphenols from kinnow (Citrus reticulate L.) peel using ultrasound and maceration techniques. Journal of Food and
Drug Analysis, 25(3), 488-500. https://doi.org/10.1016/j.jfda.2016.07.01 0

Wahdaningsih, S., Setyowati, E. P., \& Wahyuono, S. (2011). Aktivitas Penangkap Radikal Bebas Dari Batang Pakis (Alsophila glauca J.Sm ). Majalah Obat Tradisional, 16(3), 156-160. 